\title{
AUDITING FAIR VALUES IN A SENSITIVE SOCIO-ECONOMICAL CONTEXT
}

\author{
Nicoleta Farcane $e^{1}$ \\ Delia Deliu ${ }^{2}$ \\ Maria Gheorghian ${ }^{3}$
}

ABSTRACT: The concept of fair value was subject of many debates and disputes in recent years. These debates have focused mainly on the relevance of the concept, but also on the practical difficulties in determining reasonable estimates, raising particularly the interest of practitioners in terms of identifying the best valuation procedures and techniques, respectively auditing fair values. Determining the fair value involves a broad spectrum of approaches, from the simplest to the most complex and burdensome ones. In the current socio-economical context, market and stock volatility raises questions about fair values, even if there are conditions for the existence of market information. The problem gets more complicated where fair value is determined based on cashflows, especially where there are uncertainties about the value and timing of cash-flows and adjustment rates, and the impact of used assumptions related to future conditions, transactions and events.

Last but not least, assessment of fair value is based on the going concern assumption, which may not be applicable in the context of an economic crisis.

The International Financial Reporting Standards (IFRS) provide for financial instruments to be measured generally at fair value. Because fair value is primarily assimilated with market price, its assessment requires the existence of a market able to operate under normal conditions, or in other words, sufficiently liquid to assess the price of financial instruments. And, one of the features of the current crisis consists in the significant decrease of liquidities on the market, which in turn caused a high impairment of derivatives (those based on American real estate). As American real estate can never be zero, market prices are not the real ones. However, this situation highlights the volume of liquidities available to buyers, which is a feature of imperfect markets. But the International Financial Reporting Standards did not anticipate the effects of liquidities on financial instruments, as their development is based on perfect functioning of financial markets. Under these circumstances, fair value measurement started to be increasingly criticised, and the International Accounting Standards Board (IASB) has changed the rules for measurement of financial instruments at fair value.

Given the high degree of volatility, auditors should ensure that valuation methods and assumptions used by management under normal conditions for determining fair values are appropriate in a sensitive socio-economical context as well, and that the valuation model includes also the effects of subsequent events.

Key words: fair value, historical costs, fair value audit, volatility, economic crisis

JEL codes: M10, M40, M42

\footnotetext{
${ }^{1}$ West University of Timişoara, România, e-mail: nicoletafarcane@yahoo.fr.

${ }^{2}$ West University of Timişoara, România, e-mail: delia.deliu@yahoo.com

${ }^{3}$ Valahia University of Târgovişte, România, e-mail: mariagheorghian@yahoo.com
} 


\section{Introduction}

The purpose of this article consists mainly in enriching specialised information on auditing fair value for the activity of auditors in Europe, especially in a sensitive socio-economical context like the current crisis.

This article was prepared based on the analysis of specialised national, European and international literature on aspects related to fair value assessment, valuation and audit (techniques for valuation of financial statements' reliability), which allowed us to position our results in the current economic context, featured and governed by uncertainty due to the limits and challenges imposed by the financial crisis.

The article presents the current trends around a concept that has become of great interest in the context of the new economic conditions, respectively fair value measurement as alternative to historical costs, as well as the impact of the financial crisis on auditing fair values.

The main goal of this article consists in identifying and recommending audit procedures and techniques to be applied by auditors in respect of measuring the appropriateness of management assumptions that represent the basis for fair value accounting estimates in the current economic crisis. This was done in parallel with defining the theoretical general concept of "fair value" (advantages, disadvantages).

The article is a descriptive research, which at a later stage will try to explain the facts observed, being intended to strengthen practical expertise in financial audit, in order to improve the profession's specific tools. Thus, the methodological and scientific tools used for this article are based on review, systematic analysis of literature and interpretation (deductive and inductive reasoning), belonging to the qualitative research methods.

\section{Premises for the conceptual approach of fair value}

The fair value concept is very broad and subjective, because the very definition is different depending on the considered accounting referential. Currently, two accounting standard sets are dominant at global level: the International Financial Reporting Standards - IFRS and the Generally Accepted Principles - US GAAP. While IFRS are based on principles (Le petit Robert, 1993) and allow certain flexibility for companies and auditors, US GAAP are based rather on very detailed and exhaustive rules (Le petit Robert, 1993).

Definition of fair value within IASB project is similar to that of SFAS 157 Fair Value

\section{Measurement:}

"Fair value is the price that would be received for selling an asset or paid for transferring a liability in an orderly transaction between market participants at the measurement date (exit price)".

The bankruptcy of large American companies (Enron, WorldCom, Xerox) has brought again into question the myth of reliability and relevance of information disclosed in accordance with US GAAP, which - in our opinion - reveals the higher quality of principle-based standards, such as IFRS.

The goal of fair value measurement consists in allowing companies to reflect the best price estimate that would be obtained in transactions under normal market conditions. To achieve this goal, companies must include in the process of fair value measurement all available information related to future cash-flows and adjustment rates.

Under fair value measurement companies report losses when fair values of assets decrease (assets are transferred), respectively increase in case of liabilities (debts are paid continuously). These losses lead to a decrease in reported equity or in the company's revenues.

Because there is no actual transaction, accounting only provides information on what could happen.

In a fair value accounting model, measurement of the company's performances during a certain period of time will include both the achieved and not-achieved results (assessed based on 
either market price or internal estimates). At this level it will be difficult to distinguish between objective measurement of the company's own management and the market effects on the value of the balance sheet items. A fair value measurement for all balance sheet items presumes giving up the achievement criteria and meanwhile the loss of transaction basis for the income statement.

Reliability, objectivity, and neutrality are indispensable qualities in accounting, which cannot be assigned to the fair value measurement of all balance sheet items. In terms of management, many persons do not accept the use of fair value measurement as a means of financial administration and reporting. Moreover, some users of financial information - particularly, banks and insurance companies - do not agree with fair value measurement for all balance sheet items. If financial statements would be measured at fair value while some users of financial information do not want this, they will lose all meaning and interest and therefore they will no longer be exploited, which may lead to an adverse result than the desired and sought one.

We often wonder about reasoning that contributes to the choice between a valuation model and another (obviously, where the lawgiver allows this!), about the amount of accounting truth provided by valuation models. Nevertheless, the accounting truth is a compromise between information producers, auditors and information users.

Is there a connection between fair value measurement and the economic crisis? The impact of the American regulations.

In recent years, both theoreticians and practitioners have conflicting discussions about fair value measurement in relation to historical cost measurement.

Some authors and accounting professionals believe that encouraging the use of fair value measurement model was one of the main elements that led to the current financial crisis, because in recent years large financial institutions have disclosed in their financial statements losses of more than 150 billion dollars largely based on the use of market values (Beeler et al., 2009).

Meanwhile, (U.S.) Securities and Exchange Commission (SEC) currently investigates the possibility for certain companies under analysis to have used different market values for the same securities. In this respect, nobody can deny that the use of market values involves some problems, especially in very difficult periods in terms of market.

Therefore, we emphasise that in conditions of uncertainty, risks, price volatility and limited liquidity, fair value accounting has to face new challenges.

Thus, with the economic crisis of 2008 the concept of fair value shaped into two types of divergent opinions, respectively:

- a view that fair value accounting creates difficulties and misstatements in reflecting economic phenomena, and

- a view that the use of this value allows companies to bring the company's assets and liabilities to the current market values.

The upholders of the concept consider that fair value "is not the cause of the current crisis, but in fact it is the only realistic method for accounting of derivatives in order to disclose them in the annual financial statements" (ACCA, 2009).

The main argument finds its motivation in its ability to provide some connection to reality, together with another aspect of reality, respectively the own shortcomings of alternatives for market values. We refer here to the fact that the reflection of the value of certain elements solely based on their costs according to the historical cost principle would also not provide investors a better picture of the problems currently faced by financial institutions (Mati $\square$ D., Bonaci C.G., 2009).

SFAS 157 Fair Value Measurement issued by FASB in 2006 seems on the one hand to shake the measurement based on historical costs, but in the same time to be harmless because it does not impose fair value on a large scale (Miller and Bahnson, 2007). In fact, as usual, the truth is somewhere between, meaning that the standard takes a little of each. 
Another effect was to prepare the way for SFAS 159 The Fair Value Option for Financial Assets and Financial Liabilities, which creates the possibility for introducing and using fair value in the financial statements by new ways. Another merit of this standard is that it prepares financial reporting for the new Conceptual Framework developed by FASB. In this context, the development of SFAS 157 is fully justified, as it was intended to "put order" and clarify the significance of fair value, but also its proper assessment possibilities.

Thus, it is clear that the aim of issuing SFAS 157 consists in granting uniformity and consistency to specialised literature, but especially to accounting practice. One of its greatest contributions consists in providing a real catalogue with situations in which fair value measurement is used - an appendix to the standard presents more than 60 cases in which fair value is measured and reported.

Today we feel the effects of implementing SFAS 157 - a number of financial institutions involved in loan guarantee systems stated that they were significantly affected by the implementation of accounting standards on fair value. Due to the recent problems caused by sub prime loans, SEC intends to issue soon guidelines that will allow companies to consider a wider range of values when assessing assets and liabilities by marking to market. For those inclined to blame accounting, the real culprit in the sub prime mess is a fairly new standard - SFAS 157 (quoted by Beeler, 2009).

In this respect, we should encourage the application of a system based on principles rather than rules, which is the current trend in development of IFRS by the international body.

However, fair value measurement provides a high level of transparency and clarity for most financial transactions and, consequently, it has significant advantages over other valuation methods.

Nevertheless, to this end, experts recommend IFRS to provide consistency in the use of this term. Therewith, as reported by PricewaterhouseCoopers (Price Water House Coopers, 2009) specialists, "we have to accept that in the context of IFRS the use of fair value measurement should not be extended, given the issue related to credibility of values on markets that lack liquidities".

When market liquidity is seriously damaged, as it is the case in crisis conditions, the use of fair value could cause difficulties for companies that prepare financial statements. In this case, companies must simulate potential transactions, even if it is possible for actual transactions to take place only at a later stage.

Thus, accountants must take into account the following aspects:

- measurement goal - fair value estimates are expressed in terms of current transaction value or balance sheet item, based on the conditions prevailing at the measurement date;

- the need to include reasoning and assumptions that can be made by third parties, and by experts employed by the company or the auditor;

- availability of information and their credibility and reliability degree;

- features of assets and liabilities for which fair value measurement can or must be applied;

- selection and complexity level of acceptable measurement techniques and models;

- the need to adequately disclose the measurement methods and uncertainty in the financial statements

Given the current economic situation and the aspects mentioned above, there is a growing need for guidance and clear and accurate rules on accounting measurement, both for those who prepare financial statements and for those who audit them.

Currently, the recommendations on accounting measurement and especially fair value measurement are contained and spread in many IFRS, but there are also situations when these are conflicting.

Both standard-setters and academics failed so far to bring a viable solution vis-à-vis the debate related to historical cost versus fair value. In turn, the difficult choice between historical cost and fair value includes many debates. 
The current trend with regards to orientation towards market-based measurements, which we think will continue - both in risk management and for accounting purposes - will require certain skills from assessors and auditors, which will have to be proven. Institutions will have to prove their ability to make intelligent and justified assessments for assets and liabilities in the balance sheet, including complex derivatives such as those in the centre of the current crisis.

As in the case of a driving licence, these proofs are designed to provide the company's auditors reasonable assurance that the evaluator has sufficient knowledge and skills to not cause damages to other involved third parties (Deventer D.R., 2008).

One thing confirmed by the current financial crisis vis-à-vis the fair value is that the most dangerous situation is created when the entire valuation process is based on the company that trades the securities, with no independent confirmation about the provided values from an auditor or a risk management institution (Deventer D.R., 2008).

\section{Fair value - pros and cons}

The measurement model chosen for the preparation of the financial statements could materially influence the quality of the provided financial information and, hence the value of the published financial statements. Specialised literature mentions both advantages and disadvantages for the main valuation models - historical cost and fair value, which will be pointed out below.

Several authors considered that the arguments in favour of fair value measurement or historical cost accounting must be weighted more carefully in situations where business continuity is threatened, like in the current socio-economical context.

For example, Schwartz (Shwartz K., 2001) examines the case of a company in liquidation, where there must be chosen between historical cost and fair value reporting. The author stresses the importance of choosing a suitable reporting basis in order to comply with accounting regulations in force, to publish financial statements relevant for all stakeholders, and to reduce litigation risks. Auditors are also interested in the measurement model chosen by companies, and according to Martin et. al (Martin D.R., Rich S.J., Wilks T.J, 2006) they must understand not only how fair value measurement has been performed and the potential difficulties faced in the measurement, but also the errors that could appear in auditing fair values.

Among the primary advantages of fair value we should note that this is a concept, which finds its counterpart in the value that can be added to the business by selling or settling that item.

Also, fair values have greater transparency. When a fair value is established based on prices existing on liquid markets, such an assessment implies even fewer estimates than in case of using depreciated historical costs. At the same time, fair value is also a more transparent concept in the sense that the "position" is publicly known, whether favourable or unfavourable.

Moreover, fair value also has the advantage of being a value that incorporates many more useful information, since it is based on existing market conditions and it reflects the "positions" of all market participants, and not just the vision of one participant, respectively the position of the reporting company (historical cost is a value specific for a single company).

On the other hand there are opinions, which argue that "fair values may be the target of manipulations, so that financial statements reflect the results desired by managers"(Linsmeier T.J., 2009). However, the adepts of fair value consider that in practice the main alternative to fair value i.e. historical cost - can become much easier subject to advantages pursued by management. For example, for investments at historical cost, for which also a realisable value can be established, profits may be influenced only based on management decision to sell those assets in the reporting period. Moreover, in a cost-based system and under the conditions of a more rapid development of contracts dealing with derivatives, a wide range of assets (and even liabilities) has not been presented in the balance sheet because they have immaterial or null costs. Nevertheless, the value of these elements can always increase or decrease as a result of events taking place on the market (interest rate changes, exchange rate changes, price of goods, etc.). In case of derivatives, fair value 
is the only realistic method for reflecting the results of transactions in the balance sheet. In such cases, fair value is the only reliable basis.

Thus, we can conclude that the adoption of a single valuation basis for assets and liabilities would allow avoidance of many problems associated with accounting of financial instruments (for example, difficulties arising from defining the limits between different categories of instruments or those related to the reclassification from one category to another). However, as argued by many specialists, the use of fair value model cannot be extended to other assets categories before knowing the value's ability to provide credibility to the users of financial statements.

\section{a. Disadvantages of using fair value}

In our opinion, the most important cons for the use of fair value are as follows:

- fair value cannot ensure the accuracy of historical cost;

- lack of active and liquid markets, leading to a subjective fair value;

- risks involved by using models (the past does not represent a reliable basis for measuring future);

- it does not reflect management's intention to keep the asset, but only to sell it;

- it bids a perspective of market participants, and not of the companies themselves;

- when the market declines, fair value measurement can determine failure to comply with the criteria for capital preservation.

Based on the views of large international investors associations, the main shortcomings and weaknesses of fair value are as follows:

\section{Its definition in the International Financial Reporting Standards}

In this respect, according to IASB, fair value is defined in a consistent manner as a current market output value, which corresponds to a lot of cases in which fair value is used. However, ACCA experts argue that "there are cases - for example, when fair value is used as a substitute for cost when another definition would be appropriate for this term (for example, as input value, including transaction costs)" (ACCA). In any case, it is obvious that fair value is part of the category of valuation concepts based on current values, together with replacements cost and usage value.

2. Use of fair value can create pro-cyclicality in the financial statements, by accelerating market decrease through encouraging sales for fulfilling the capital conditions

When the economy is growing or declining through a series of repetitive booms or recessions, the term "pro-cyclicality" describes all those mechanism by means of which the financial system may have a reaction in terms of amplification of actual market fluctuations, thus leading to an excessive financial instability.

Thus, given that the fair value principle does not involve an actual transaction in order for the value changes to be recognised in accounting, the use of this value may lead to premature recognition of profits or losses, unlike the case in which the historical cost approach would have been used.

Therefore, when the market is growing, fair value measurement may lead to higher values and, thus, to the overstatement of profits in the financial statements, and when the market is down it may lead to overstatement of losses, thus creating the pro-cyclicality phenomenon.

Consequently, there are experts who argue that the use of fair value encourages banks to grant excessive loans when the market is favourable, and to exaggerate the financial problems faced in less favourable economic conditions, and therefore fair value is able to determine and influence the behaviour of banks, without being limited to reflecting banks' activities.

3. However, the biggest problem caused by the use of fair value refers to its credibility.

Although under normal conditions, when the market is liquid, there are market prices available and transactions have safe basis, the use of fair value does not raise special problems, its extended use on financial instruments that are not listed on the market creates high risks. Moreover, another aspect reported by banks as a result of the economic crisis referred to markets lacking liquidities or ceasing to exist, which made assessments to be affected by uncertainty.

\section{b. Advantages of using fair value}


In our opinion, the most important pros to use fair value are as follows:

- fair value represents the only valuation basis that can be attributed to derivatives;

- fair value includes current information

Fair value accounting fulfils the qualitative features of financial information in a higher manner than historical cost accounting. Among the positive features of the fair value concept we can mention:

1. Clarity and transparency - fair value accounting is partially true because it largely reflects the conditions to be met by the financial information in order to be reliable, namely: $i t$ reflects reality accurately (by valuation and disclosure of elements at their current value), it respects the principle of substance over form (because it requires valuation of all items at fair value, even if the value is not recognised for tax purposes), it reflects the completeness of accounting information (by recognition in accounting of items that would have been omitted in historical costs, for example derivatives).

2. Intelligibility and provision of complex information - because currently there is an increasing demand for disclosing additional information in appendices related to the calculation and recognition of fair value of elements included in the financial statements;

3. Fair value accounting requires or allows companies to report values with a high degree of opportunity and comparability, including under exceptional market conditions, in comparison to the case when these would have been reported by using other valuation bases;

4. Fair value accounting requires or allows companies to report values that are subject to continuous adjustments;

5. It limits managers' ability to manipulate net income because any gains or losses from assets and liabilities are reported when they occur and not when they are actually done within actual transactions;

6. Gains and losses arising from changing fair value estimates reflect economic events that may require disclosure of additional information useful to investors in making decisions;

7. It provides an adequate accounting for derivatives

However, as mentioned above, fair value is not neutral because it is easy to manipulate - for example, by disclosing higher values for assets in order to reflect a positive image of the company. Moreover, fair value accounting is not prudent, because it allows recognition of unrealised gains in the income statement.

However, we believe that it is preferably to have an accurate transparent system (based on fair value), than an accurate irrelevant historical cost.

In our opinion, the lack of active markets does not justify giving up fair value, but development of valuation methodologies.

Therefore, the criticism brought to fair value really addresses problematic situations, but the proposed solution - usage restriction - is still unconvincing due to at least three reasons. They do not bring viable alternatives, they ignore the negative impact that would result in loss of information that is currently provided in the financial statements, and they affect the distinction between accounting and prudential activities, which in fact have different aims and should be separated with more attention (Veron, 2008). Opponents of fair value lost this dispute from the beginning, because they are able to accompany their arguments with tangible solutions, or in other words with a "counter-offer".

Another important aspect highlighted in specialised literature is that such a serious crisis like the current one, is not and cannot be caused by a single party, but it involves the incapability of the entire ecosystem that has failed to appreciate risks related to rapid growth of structured mortgage risks, which is the reverse of real estate price growth, and an unprecedented lack of liquidities (Ryan, 2008). All these factors brought to the surface an inappropriate behaviour of lenders, borrowers and investors, making them to simply ignore what common sense would have indicated, namely never forget to assess the actual involved risks at fair values. 
Fair value accounting or any other assessment method has no chance to eliminate such behaviours (Ryan, 2008). Still we should recognise that fair value has a key role in constantly providing relatively rational information to market participants and also in providing a set of common information to be used by all these participants in order to perform a recalibration of their own risk assessment when economic cycles alternate. This recalibration must take place as soon and efficiently as possible, as it should happen in our days as well. Ryan (2008), and many others mentioned above, also note that any form of historical cost would only prolong this recalibration process for longer periods, which is highly likely to worsen costs at the economic level of the crisis.

As a conclusion, we would like to highlight that fair value did not cause the economic crisis, and giving it up now, when markets are falling, will not solve the problems, but it would only restrain investors from receiving useful information and would affect accounting neutrality, as well the independence of the lawgiving bodies.

\section{Fair value audit - challenges of the economic crisis}

October 2008 was marked by an "alert" of the International Accounting Standards Board (IASB), which issued the document "Challenges in Auditing Fair Value Accounting Estimates in the Current Market Environment" in order to assist auditors by highlighting parts of the International Standards on Auditing (ISA), which are relevant for auditing accounting estimates, including fair value accounting estimates, defined by ISA as ,an approximation of a monetary value in the presence of an accurate measurement method, such concept being used for a value assessed at fair value under conditions of estimate uncertainty and for other values that require an estimate" and related disclosures, in a sensitive socio-economical context like the financial crisis. The document was prepared in light of difficulties encountered on loan markets, and consequently it focuses especially on financial instruments, referring also to situations where it is uncertain whether the company can continue its activity or not (on-going concern). The alert is particularly important and relevant for auditors with clients holding investments in financial instruments, especially on nonliquid markets.

In our opinion, the vital topics are as follows:

- challenges of fair value accounting;

- requirements and guidance on standards that are particularly relevant for the fair value concept;

- other considerations vis-à-vis auditing accounting estimates, including fair value accounting estimates;

- IASB initiatives; and

- Recent reviews of standards on auditing accounting estimates, including fair value accounting estimates and related disclosures.

Valuation and disclosure of fair value is extremely important in many accounting standard sets. Thus, auditors should be aware of the need to understand the principles and rules that refer to fair value accounting, including related disclosures, respectively to give due importance to their application.

Recent market events and experiences have proven the difficulties arising from assessment of financial instruments when information is either not available, or insufficient.

The auditor should obtain sufficient appropriate audit evidence to prove that assessments and disclosures of information related to fair value are in compliance with the company's applicable financial reporting framework.

Fair value measurement can be achieved by using the valuation model (for example, a model starting from future cash-flow projections and adjustments) or with the assistance of an expert, such as an independent evaluator.

Management is responsible for measurement and disclosure of information on fair value included in the financial statements. As part of its responsibility, management should set up and design an accounting and financial reporting process for determining measurement and disclosure 
of information on fair value, to select appropriate assessment methods, to identify and adequately support any significant assumptions used, to prepare the measurement and to ensure that disclosures regarding fair value measurement are in compliance with the company's identified applicable reporting framework (ISA 545).

Many measurements based on estimates, including fair value measurements, are inherently imprecise. In case of fair value measurements, especially those that do not involve contractual cashflows or for which no market information are available when conducting the estimate, fair value estimates often involve uncertainty in respect to both the value and timing of the future cash-flows.

Fair value measurements can be based also on assumptions about future conditions, transactions or events, whose outcome are uncertain and therefore will be subject to changes over time.

Different financial reporting frameworks require or allow a variety of assessments and disclosures related to fair value information in the financial statements. They also differ in terms of guidance offered in relation to the basis of valuation of assets and liabilities or other related information disclosures. Certain financial reporting frameworks offer prescriptive guidance, others general guidance, while others do not offer guidance at all. Moreover, there are assessment and disclosure practices for fair value information that are industry-specific.

ISA 545 provides guidance on auditing measurement and disclosure of information on fair value, but it does not address specific types of assets or liabilities, transactions or industry-specific practices. The appendix to this standard discusses about measurement and disclosure of information on fair value based on different financial reporting frameworks and about prevalence of fair value measurement, including the fact that there are different definitions of "fair value" according to such frameworks. For example, International Accounting Standard (IAS) 39 "Financial Instruments: Recognition and Measurement" defines fair value as "the value at which an asset could be changed or a debt settled between knowledgeable and willing parties in a transaction concluded under objective conditions".

In most financial reporting frameworks, the basis for fair value measurement is represented by the assumption that the company is a going concern, without any intention or need to be liquidated, significant decrease of its activities or conclusion of a transaction under unfavourable conditions. Therefore, in this case, fair value cannot be the the value that would be received or paid by the company in a forced transaction, involuntary liquidation or forced sale. However, the company might be forced to consider its current economic or operational situation when determining the fair value of its assets and liabilities, if this is required or allowed by its financial reporting framework and such a framework could foresee or not the way to proceed. For example, management's plan to sell an asset on an accelerated basis to meet certain specific business objectives may be relevant for determining the fair value of that asset.

Calculation of fair value can be relatively simple for certain assets or liabilities - for example, assets bought and sold on active open markets that offer easily obtainable and reliable information on prices used in actual exchanges. Calculation of fair value for other assets or liabilities may be more complex. A certain asset may have an active market or features that imply fair value estimates by management (for example, a real estate investment or a complex derivative). Fair value estimates can be achieved by using an evaluation model (for example, a model based on future cash-flows projections and adjustments) or with the help of an expert, such as an independent evaluator.

Uncertainty together with another element or the lack of objective data may lead to the fact that the asset cannot be reasonably estimated, and in such cases the auditor considers whether the audit report should be amended to comply with ISA 700 "Auditor's Report on Financial Statements".

The degree to which a fair value measurement is likely to be misstated is an inherent risk. Consequently, the nature, duration and extent of further audit procedures will depend on the 
susceptibility of misstatement of a fair value measurement and whether the fair value measurement process is relatively simple or complex.

ISA 315 "Identification and Assessment of Risks of Material Misstatements by Understanding the Company and its Environment" discusses the inherent limits of internal control. Since the determination of fair value often involves subjective reasoning by management, this may affect the nature of the control procedures that can be implemented. Susceptibility related to misstatement of fair value measurement may increase with the complexity of the financial and accounting reporting requirements for fair value measurement. In such situations, the auditor considers the inherent limitations of control by assessing the risk of material misstatement.

\section{a. Consultation with a specialist or expert - ISA 620}

In our opinion, determining fair value may require the assistance of a specialist or expert, due to the complex aspects faced by the audited company. We say this because availability and reliability of information available to management for determining fair value can vary greatly, affecting the certainty of its estimates. If markets are no longer active, available information is reduced and valuation models are no longer reliable. What was once considered a routine valuation matter now can become the source of material risks. All these uncertainties do not exonerate the auditor from the obligation of obtaining appropriate, relevant and sufficient audit evidence.

Matters to be considered by the auditor during the evaluation of appropriateness of assumptions used by management for making fair value accounting estimates may include, for example:

- how management integrated initial market-specific data in the developed assumptions - where relevant;

- if assumptions correspond to observable market conditions and features of assets or liabilities valuated at fair value;

- if the sources of assumptions made by market participants are credible and relevant, and how management has selected the used assumptions;

- how management assessed the assumptions used in comparable transactions - where relevant.

\section{b. Assessment of appropriateness of information measurement and disclosures - ISA 545}

The auditor should review whether measurement and disclosure of information on fair value in the financial statements comply with the company's financial reporting framework.

The auditor's understanding of the requirements of the financial reporting framework and knowledge of the company and its industry, together with the results of other standard procedures, are used to check whether the accounting of assets and liabilities requiring fair value measurement is appropriate and whether disclosures of information on fair value measurement and related significant uncertainties are in accordance with the company's applicable financial reporting framework.

Estimation techniques and assumptions, as well as comparison of fair value measurement from prior periods with results obtained in the current period, if applicable, may provide audit evidence on the credibility of the process used by management. However, the auditor also checks if such variances do not result from changes in economic circumstances.

In order to perform fair value measurements, management should develop assumptions, including those based on the work of an expert. Consequently, management assumptions also include those developed under the guidance of those in charge with governance.

\section{Conclusions}

The economic world and the International Accounting Standards Board (IASB) could benefit from the experience of the economic crisis in order to improve and complete the financial reporting framework.

Also, we are convinced that the topic of fair value will be an aspect to be considered within the convergence programme between IASB - the International Accounting Standards Board and the 
American counterpart, FASB - the Financial Accounting Standards Board, and it (raised) and will continue to raise the interest of practitioners for identifying the best procedures and techniques for auditing fair value.

Fair value measurement is a system that has already penetrated the regulatory environment, being in a continuous development. In a globalize market capital and complex financial instruments it is obvious that for investors fair value of assets and liabilities has an increased interest in comparison to historical cost, an important aspect being its presentation not only on short-term, i.e. based on market expectations, but rather on long-term, based also on the intention on how to generally use assets, and not only for their valorisation.

We believe that the current emphasis on the need to improve transparency related to fair value will have a beneficial effect by simply bringing into discussion again a somewhat exaggerated debate, the search for solutions leading finally to the problems' origins, making us once again aware of the financial market theories, as shown for the current financial crisis. Another fact to remember is that investors make their own adjustments on available information (or at least this is what the behaviour of a responsible investor presumes) in the attempt to make them useful for their own needs. This approach reduces to some extent the importance of the fact that information is first processed by companies and enchained by accounting regulations. In other words, the market needs transparency in a greater extent than it needs standards (Rérolle, 2008).

This crisis in international standardisation is not necessarily a strictly technical crisis due to fair value criteria, but it is rather an intellectual crisis related to the conceptual framework.

The limits of our research can be expressed mainly about the fact that we were only able to perform a review of specialised literature in comparison to the research main goal, and in future stages we will proceed to an integration by field observation, intending to conduct semi-directive interviews in audited companies, and to observe development and use of detailed tools and procedures related to fair value application on assets.

\section{References}

1. Barlev B., Haddad J.R., 2003. Fair value accounting and the management of the firm, Critical Perspectives on Accounting 14, pg. 383-415

2. Barth E.M., Landsman W. R., 2009. How did financial reporting contribute to the financial crisis, European Accountign Review, vol. 19, p. 399-423

3. Barth E. M., Landsman R. W., Wahlen M. J., 1995. Fair value accounting: Effects on banks' earnings volatility, regulatory capital, and value of contractual cash flows, Journal of Banking and Finance 19, pg. 577-605.

4. Barth E.M., Landsman W. R., 1995. Fundamental issues related to using fair value accounting for financial reporting, Accounting Horizons, vol. 9, p. 97-107

5. Beatty A., Chamberlain S., Magliolo J., 1996. An empirical analysis of the economic implications of fair value accounting for investment securities, Journal of Accounting and Economics 22, p. 43-77

6. Beeler J., Evans A., Turner K., 2009. How Fair is Fair Value, Proceedings of American Society of Business and Behavioral Sciences, vol.16, no.1

7. Beisland, L. A, 2010. A note on fair value accounting in a crisis: The influence of the hedge accounting regulations, Business and Economics Journal, vol. 2010: BEJ-13

8. Bhargava R., Dubofsky A. D., 2001. A note on fair value pricing of mutual funds, Journal of Banking and Finance 25, pg. 339-354

9. Bischof J., Brüggemann, U., Daske, H., 2010. Relaxation of fair value rules in times of crisis: an analysis of economic benefits and costs of the amendment to IAS 39, May 2010

10. Bizon M., 2010. Poli de opinie cu privire la utilizarea valorii juste în condițiile economice actuale, Audit Financiar, mai 
11. Botosan C.A., Beatty A.L., Hopkins P.E., Nelson K.K., Venkatachalam M., 2005. Response to the FASB's Exposure Draft on Fair Value Measurements, Accounting Horizons, vol. 19, no.3, p.187-196

12. Cornett M. M., Rezaee Z., Tehranian H., 1996. An investigation of capital market reactions to pronouncements on fair value accounting, Journal of Accounting and Economics 22, pg. $119-154$

13. Deventer D.R., 2008. Fair-Value Accounting, CDOs and the Credit Crisis of 2007-2008, Bank Accounting \& Finance, October-November 2008, p. 3-8

14. Dietrich J. R., Harris S.M., Muller A.K., 2001. The reliability of investment property fair value estimates, Journal of Accounting and Economics 30, pg. 125-158, accesibil la www.elsevier.com/locate/econbase

15. Elliott B., Elliott J., 2005. Financial Accounting and Reporting, Pearson Education Limited, 9th Edition, Harlow Essex

16. Feleagă N., Malciu L., 2004. Provocările contabilităţii internaţionale la cumpăna dintre milenii. Modele de evaluare şi investiţia imaterială, Editura Economică, Bucuresti

17. Fiechter P., 2010. The effects of the fair value option under IAS 39 on the volatility of bank earnings, Journal of International Accounting Research

18. Hann N. R., Heflin F, Subramanayam K.R., 2007. Fair value pension accounting, Journal of Accounting and Economics 44, pp. 328-358

19. Hitz, J., 2007. The decision usefulness of fair value accounting - a theoretical perspective, European Accounting Review, no 16, pp. 323-362

20. Hughes J., Tett G., 2008. An unforgiving eye: bankers cry foul over fair value accounting, Financial Times, 14 March

21. Landsman W.R., 2006. Fair value accounting for financial instruments: some implicatios for bank regulations, BIS Working papers, No. 209, Monetary and Economic Department

22. Landsman W.R., 2007. Is fair value accounting information relevant and reliable? Evidence from the capital market research, Accounting and Business Research (Special Issue: International Accounting Policy Forum), p 19-30

23. Laux C., Leuz C., 2009. Did fair value accounting contribute to the financial crisis?, National Bureau of Economic Research, 2009

24. Laux C., 2009. Fair value Accounting and procyclicality - regulatory challenges, Conference working papers, Accounting, Organizations and Society, no 34, 2009

25. Laux C., Leuz C., 2009. The crisis of fair value accounting: making sense of the recent debate, 2009, Chicago Booth Research Paper no. 33 http://papers.ssrn.com/sol3/papers.cfm?abstract_id=1392645

26. Liao L., Kang H., Morris R., Tang Q., 2011. Information asymmetry of fair value accounting during the global financial crisis, AFAANZ, July

27. Magnan M., 2009. Fair value accounting and the financial crisis: messenger or contributor?, Cirano Scientific Series, available online at http://www.cirano.qc.ca/pdf/publication/2009s27.pdf

28. Martin D. R., Rich S.J., Wilks T.J., 2006. Auditing Fair Value Measurements: A Synthesis of Relevant Research, Accounting Horizons, vol. 20, nr.3, pg. 287-303

29. Matiş D., Bonaci C.G., 2010. Raportarea financiară şi învăţăminte în vremuri de criză, Note de curs, FSEGA Cluj

30. Miller P.B.W., Bahnson P. R., 2007. FASB 157 upgrades the quality of financial reporting, Journal of Accountancy, November, p. 30-36

31. Pozen R.C., 2009. Is it fair to blame fair value accounting for the financial crisis?, Harvard Business Review, available online at http://hbr.org/2009/11/is-it-fair-to-blame-fair-valueaccounting-for-the-financial-crisis/ar/1 
32. Prochazka D., 2010. Should we really blame fair value accounting for the financial crisis?, Recent Researches in Sociology, Financing, Environment and Health Sciences, available online at http://www.wseas.us/elibrary/conferences/2011/Meloneras/SOMMEM/SOMMEM-27.pdf

33. Ramanna K., 2008. The implications of unverifiable fair value accounting: Evidence from the political economy of goodwill accounting, Journal of Accounting and Economics 45, 253-281

34. Ratcliffe T.A., 2007. The Finer Points of Fair Value FASB 159 opens up options, Journal of Accountancy, December 2007, pp. 30-36

35. Ronnen J., 2008. To Fair Value or Not to Fair Value: A Broader Perspective, Abacus, vol. 44, no. 2, pp. 181-208

36. Schwartz K., 2001. Going concern gone: anatomy of a corporate liquidation, Journal of Accounting Education, 19, pp. 129-143

37. Shaffer S., 2010. Fair value accounting: villain or innocent victim? Exploring the links between fair value accounting, bank regulatory capital and the recent financial crisis, Federal Reserve Bank of Boston, WPS No QAU 2010-01

38. Skinner J.D., 2008. Discussion of "The implications of unverifiable fair-value accounting: Evidence from the political economy of goodwill accounting", Journal of Accounting and Economics 45, 282-288

39. Song C.J., Thomas W.B., Yi H., 2009. Value relevance of FAS 157 Fair value hierarchy information and the impact of corporate governance mechanisms, The Accounting Review, no 85 , p. $1375-1410$

40. Turley S., 2008. Discussion of Ronnen, Abacus, vol. 44, no. 2, p. 209-216

41. Veron N., 2008. Fair Value Accounting is the Wrong Scapegoat for this Crisis, Accounting in Europe Vol. 5, No. 2, pp. 63-69

42. Wallace M., 2008. Is Fair-Value Accounting Responsible for the Financial Crisis?, Bank Accounting \& Finance, December 2008 - January 2009, pp. 9-18

43. Zyla L., Mark L., Auditing fair value measures, downloadable: www.allbusiness.com

44. The Economist, 2008. The crisis and fair value accounting, 18th September, available online at http://www.economist.com/node/12274096

45. APB - Accounting Principals Board, 1970. Statement No. 4: Basic Concepts and Accounting Principles Underlying Financial Statements of Business Enterprises

46. Deloitte, 2009. Fair value: cause or vicim of the finance crisis?, Deloitte Academy Insurance Breakfast, 4th March

47. Ernst \& Young, 2008. Fair value accounting and the current economic crisis, 4th May

48. PWC, 2008. Fair value challenges in the current environment, October

49. PWC, 2009. Fair value: clarrifying the issues

50. Financial Accounting Standards Board (FASB), 1980 (revised 2008). Statement of Financial Accounting Concepts (SFAC) No. 2: Qualitative Characteristics of Accounting Information

51. Financial Accounting Standards Board(FASB), 2004. Proposed Statement of Accounting Standards - Fair Value Measurements, Exposure Draft

52. Financial Accounting Standards Board (FASB), Standards: SFAS 107 Disclosures about Fair Value of Financial Instruments; SFAS 115 Accounting for certain investments in debt and equity securities; SFAS 119 Disclosure about derivative financial instruments and fair value of financial instruments; SFAS 133 Accounting for Derivative Instruments and Hedging Activities; SFAS 157 Fair Value Measurements; SFAS 159 The Fair Value Option for Financial Assets and Financial Liabilities

53. International Auditing and Assurance Standards Board (IASB), 2008. Challenges in Auditing Fair Value Accounting Estimates in the Current Market Environment, http://web.ifac.org/download/Staff_Audit_Practice_Alert.pdf 
54. International Accounting Standards Board (IASB), 2008. Framework for the Preparation and Presentation of Financial Statements

55. International Accounting Bandards Board (IASB), http://www.iasb.org/Current+Projects/IASB+Projects/Fair+Value+Measurement/Fair+Value + Measurement.htm

56. United States Securities and Exchange Commission(US SEC), 2008. Report and Recommendations Pursuant to Section 133 of the Emergency Economic Stabilization Act of 2008: Study on Mark - To - Market Accounting, available online at www.sec.gov/news/studies/2008/marktomarket123008.pdf

57. European Central Bank(ECB), 2004. Fair value accounting and financial stability, Occasional Paper Series, p. 3-48

58. Chamber of Financial Auditors of Romania CAFR and IRECSON Publishing House, 2009. Reglementări Internaționale de Audit, Asigurare şi Etică, Audit Financiar, 2008, Editura Irecson, Bucureşti

59. International Federation of Accountants (IFAC), 2009. Manual de Standarde Internaționale de Audit şi Control de Calitate, Audit Financiar, Editura Irecson, Bucureşti

60. International Accounting Standards Board (IASB), 2008. International Financial Reporting Standards. Handbook

61. ACCA, Policy Paper on Fair Value, available online at www.accaglobal.com/economy

62. International Accounting Standards Board, Projects Expositions http://www.iasb.org/Current+Projects 